\title{
Reassessing public opinion of captive cetacean attractions with a photo elicitation survey
}

\author{
Sophia N Wassermann ${ }^{\text {Corresp.., }}{ }^{1,2}$, Edward J Hind-Ozan ${ }^{2,3}$, Julia Seaman ${ }^{4}$ \\ 1 Ryan Institute, National University of Ireland, Galway, Galway, Ireland \\ 2 Center for Marine Resource Studies, The School for Field Studies, South Caicos, Turks and Caicos Islands \\ 3 Sustainable Places Research Institute, Cardiff University, Cardiff, Wales, United Kingdom \\ 4 Babson Survey Research Group, Babson College, Babson Park, Massachusetts, United States \\ Corresponding Author: Sophia N Wassermann \\ Email address: s.wassermann1@nuigalway.ie
}

Background. Captive cetacean attractions are growing in number globally, their operators citing entertainment, education, and conservation as benefits. Those for and against developing such attractions claim public support. Previous public opinion research, however, shows little consensus, partly due to the introduction of biases in study design that influence participants' responses. Those involved in, or concerned with, developing and licensing these attractions need to better understand what drives the lack of consensus to take socially-acceptable decisions.

Methods. We reviewed previous research on public opinion of cetacean captivity, noting possible sources of bias. Survey question wording can be a major source of introduced bias, so we used an openended photo elicitation approach. We showed tourists in the Turks Caicos Islands $(N=292)$ images of a marine mammal park (MMP) killer whale show and a swim-with-the-dolphins (SWTD) attraction and asked for their qualitative comments on the potential development of each. They also indicated how likely they would be to visit each on a Likert scale.

Results. Respondents were generally against visiting MMP killer whale shows, with 60.9\% not likely to visit. SWTD attractions were more popular; $60.3 \%$ were likely to visit. For SWTD, USA residents were more likely to visit; older respondents and those staying in all-inclusive resorts were less likely. Those staying in all-inclusive resorts were also less likely to visit MMP killer whale shows. The great majority of qualitative comments centred on either entertainment value or animal welfare concerns. There were very few, if any, comments on the education or conservation value of these attractions.

Discussion. Our findings contradict several previous studies into public opinion of captive cetaceans that did not use photo elicitation. The support shown for MMP killer whale shows in this survey was well below that claimed by studies conducted on behalf of captive cetacean attraction operators. Opposition to SWTD is also noticeably lower than that found in surveys conducted with wild cetacean tourism participants. This difference can likely be attributed to the different survey populations and settings, but this variation is also very likely attributable to researcher-introduced bias. While photo selection can introduce bias, photo elicitation reduces reliance on pre-scripted questions and responses, and seems to effectively reduce other forms of bias. Allowing open-ended responses, where participants responded to an image seems to have given a more representative understanding of what is at the forefront of the public's mind, than closed questioning. These conclusions, among others made in this study, suggest that development decisions for captive cetacean attractions are being made on imprecise data. Going forward, data collected via responder-led, open-ended, bias-minimising approaches should at least be considered when informing such decisions. 
1 Reassessing public opinion of captive cetacean attractions with a photo elicitation survey 2

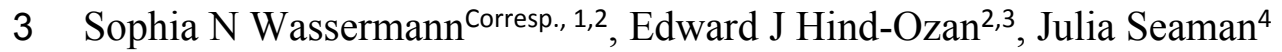

4

$5 \quad{ }^{1}$ Ryan Institute, National University of Ireland, Galway, Galway, Ireland

$6 \quad{ }^{2}$ Center for Marine Resource Studies, The School for Field Studies, South Caicos, Turks and 7 Caicos Islands.

8 3Sustainable Places Research Institute, Cardiff University, Cardiff, Wales, United Kingdom

$9 \quad{ }^{4}$ Babson Survey Research Group, Babson College, Babson Park, Massachusetts, United States 10

11 Corresponding Author: Sophia N Wassermann

12 Email address: so@sowasser.com 
14

15

16

17

18

19

20

21

22

23

24

25

26

27

28

29

30

31

32

33

34

35

36

37

38

39

40

41

42

43

44

45

46

47

48

49

50

51

52

53

54

55

56

57

58

\section{Abstract}

Background. Captive cetacean attractions are growing in number globally, their operators citing entertainment, education, and conservation as benefits. Those for and against developing such attractions claim public support. Previous public opinion research, however, shows little consensus, partly due to the introduction of biases in study design that influence participants' responses. Those involved in, or concerned with, developing and licensing these attractions need to better understand what drives the lack of consensus to take socially-acceptable decisions.

Methods. We reviewed previous research on public opinion of cetacean captivity, noting possible sources of bias. Survey question wording can be a major source of introduced bias, so we used an open-ended photo elicitation approach. We showed tourists in the Turks Caicos Islands $(\mathrm{N}=292)$ images of a marine mammal park (MMP) killer whale show and a swim-with-the-dolphins (SWTD) attraction and asked for their qualitative comments on the potential development of each. They also indicated how likely they would be to visit each on a Likert scale.

Results. Respondents were generally against visiting MMP killer whale shows, with 60.9\% not likely to visit. SWTD attractions were more popular; $60.3 \%$ were likely to visit. For SWTD, USA residents were more likely to visit; older respondents and those staying in all-inclusive resorts were less likely. Those staying in all-inclusive resorts were also less likely to visit MMP killer whale shows. The great majority of qualitative comments centred on either entertainment value or animal welfare concerns. There were very few, if any, comments on the education or conservation value of these attractions.

Discussion. Our findings contradict several previous studies into public opinion of captive cetaceans that did not use photo elicitation. The support shown for MMP killer whale shows in this survey was well below that claimed by studies conducted on behalf of captive cetacean attraction operators. Opposition to SWTD is also noticeably lower than that found in surveys conducted with wild cetacean tourism participants. This difference can likely be attributed to the different survey populations and settings, but this variation is also very likely attributable to researcher-introduced bias. While photo selection can introduce bias, photo elicitation reduces reliance on pre-scripted questions and responses, and seems to effectively reduce other forms of bias. Allowing open-ended responses, where participants responded to an image seems to have given a more representative understanding of what is at the forefront of the public's mind, than closed questioning. These conclusions, among others made in this study, suggest that development decisions for captive cetacean attractions are being made on imprecise data. Going forward, data collected via responder-led, open-ended, bias-minimising approaches should at least be considered when informing such decisions. 
59

60

61

62

63

64

65

66

67

68

69

70

71

72

73

74

75

76

77

78

79

80

81

82

83

84

85

86

87

88

89

90

91

92

93

94

95

96

97

\section{Introduction}

Since the 1960s, thousands of cetaceans have been held captive in a globally-increasing number of marine mammal parks (MMPs), aquariums, and captive swim-with-the-dolphins (SWTD) attractions (Jiang, Lück, \& Parsons, 2007). In 2018, these included 60 killer whales or orcas (Orcinus orca) (Orca Home, 2018) and near 2000 dolphins in upward of 300 facilities (Born Free Foundation [BFF], 2016; Change for Animals Foundation, 2018). Approximately 20 SWTD attractions were in the United States (US), 25 in the Caribbean, and numerous others in China, Japan and other Asian countries (Frohoff, 2003; Rose, Parsons, \& Farinato, 2009; BFF, 2016;). The existence of such attractions has become increasingly controversial, with researchers, tourism industry actors, non-governmental organisations (NGOs), and segments of the public expressing strong pro- and anti-captivity viewpoints. Further development of captive cetacean attractions will depend on how these viewpoints influence policy-makers.

Current research on the benefits and concerns of captive cetacean attractions is mixed. While some research around cetacean captivity has found benefits to human participants and cetaceans, there is research demonstrating that these benefits are falsely-perceived or short-lived (Orams, 1997; Reeves et al., 2003; Williamson, 2008; Morisaka et al., 2010; Tizzi, Accorsi, \& Azzali, 2010; Parsons, Bauer, Simmonds \& Wright, 2013). Close encounters with captive cetaceans have been documented as educational, increasing visitors' awareness of conservation issues and their likelihood to advocate for the protection of wild cetaceans (Alliance of Marine Mammal Parks and Aquariums [AMMPA], 1999; Ballantyne et al., 2007; Shani \& Pizam, 2009; Harley, Fellner, \& Stamper 2010). Yet, some contest the conservation benefits, stating the removal of animals from the wild for use in attractions puts local cetacean populations at risk (Fisher \& Reeves, 2005; Parsons, de Calventi, Whaley, Rose, \& Sherwin, 2010). The potential for MMP and SWTD human-cetacean encounters to inspire change is also questioned; studies show that visitors to captive cetacean facilities learn little about conservation (Barney, Mintzes, \& Yen, 2005; Curtin and Wilkes, 2007; Jiang et al., 2007; Rose et al., 2009; Rechberg, 2011; Dougherty, 2013). Likewise, while some research has demonstrated that these attractions benefit humans, providing entertainment (Shani \& Pizam, 2009) and improving physical and psychological health (Webb \& Drummond, 2001; Brensing \& Linke, 2003; Antonioli \& Reveley, 2005) other research has shown that any benefits are mediated by discomfort at the captive state of the animals and visitors finding the human-animal encounters too staged (Curtin, 2006; Curtin \& Wilkes, 2007; Jiang et al., 2007). Additionally, the therapeutic efficacy of human-dolphin encounters has been disputed (Marino \& Lilienfeld, 2007; Fiksdal, Houlihan, \& Barnes, 2012; Marino \& Lilienfeld, 2015). Research shows that risks to human participants, such as physical harm and disease contraction from dolphins, is possible during SWTD encounters (Mazet, Hunt, \& Ziccardi, 2004; Friend, 2006). Other studies found that any benefits from contact are superficial and transitory (Frohoff $\&$ Packard, 1995; Marino \& Lilienfeld, 2007; Williamson, 2008; Hunt et al., 2008; Fiksdal, Houlihan, \& Barnes, 2012). 
98

99

100

101

102

103

104

105

106

107

108

109

110

111

112

113

114

115

116

117

118

119

120

121

122

123

124

125

126

127

128

129

130

131

132

133

134

135

136

137

Research on whether the benefits of cetacean captivity are outweighed by animal welfare concerns is also in contention. Some research has concluded that animal behaviour can be normal and welfare high when provided with adequate enrichment; recent research has shown that dolphins positively anticipate interacting with their trainers. (Perelberg, Veit, van der Woude, Donio, \& Shashar, 2010; Tizzi et al., 2010; Clegg, Borger-Turner, \& Eskelinen, 2015; Clegg, Van Elk, \& Delfour, 2017; Serres \& Delfour, 2017; Makecha \& Highfill, 2018; Clegg et al., 2018). Yet, animals in captivity have also been found to have increased stress levels, poor diet, a higher chance of injury, and, in the case of killer whales, higher mortality rates in captivity (Kyngdon, Minot, \& Stafford, 2003; Whale and Dolphin Conservation Society [WDCS] \& The Humane Society of the United States [HSUS], 2003; Ugaz, Valdez, Romano, \& Galindo, 2013; Jett \& Ventre, 2015). In the wild, dolphins ordinarily avoid human contact (Constantine, 2001; Constantine, Brunton, \& Dennis, 2004) and research has suggested that positive response to interactions with humans may be due to habituation, or a response to ostracism from a dolphin social group, rather than a common and enjoyed behaviour (Kyngdon et al., 2003).

There is also limited agreement on the ethics of obtaining cetaceans for the attractions in question. Out of 60 killer whales in captivity (as of 6 February 2018), 27 were wild-born and 33 were captive-born (WDC, 2018). For dolphins, some of those in SWTD attractions were captured from the wild, with $70 \%$ of dolphins in marine parks in Europe born in captivity (European Association for Aquatic Mammals [EAAM], 2016). Some aquaria and captive cetacean attractions advocate that wild capture is an important conservation tool for threatened species (Bossart, 2016), but this assertion has been questioned by researchers citing the large number of individuals necessary for genetic diversity, limited available space, and high costs of captive breeding and reintroduction (Curry, Ralls, \& Brownell Jr., 2013). Possible threats to the sustainability of local populations as a result of capture have been noted in Cuba and the wider Caribbean (Waerebeek et al., 2006; Würsig, 2017). Wild capture of cetaceans in Canada ceased in 1992, but smaller cetaceans have continued to be imported (Tasker, 2018). Recently, however, cetacean captivity was banned in Vancouver (Lindsay 2018) and legislation has been put forward to ban cetacean captivity across Canada (Lake, 2018). In the United States (US), some attractions have ended their captive breeding programmes under the increased scrutiny (Hacket, 2016; Bossart 2016). However, wild-capture and breeding programmes do persist globally, e.g. a killer whale breeding facility was recently opened in China and Russia set a quota of 13 captured killer whales for 2018, destined for newly-constructed captive cetacean attractions in China (Actman, 2017; Master 2018).

The pro- and anti- arguments for keeping cetaceans in captivity have escalated in the last decade, with high-profile public debate over the ethical and conservation implications of the practice (Jiang et al., 2007; Shani \& Pizam, 2008; Thomas, 2017; Rose et al., 2017). Traditional and online/social media have questioned the continued existence of captive cetacean attractions (Coldwell, 2014; Kuo \& Savidge, 2014; Lerer, 2014; Zimmermann, 2014). The documentaries The Cove (Pesman, Stevens, \& Psihoyos, 2009) and Blackfish (Cowperthwaite \& Oteyza, 2013), which raised questions about cetacean conservation, captive cetacean welfare, and killer whale trainer safety, have increased public scrutiny of captive cetacean attractions (Rechberg, 2011; 
138 Parsons, 2012; Pernetta, 2014; Parsons \& Rose, 2018). In response, captive cetacean attraction

139

140

141

142

143

144

145

146

147

148

149

150

151

152

153

154

155

156

157

158

159

160

161

162

163

164

165

166

167

168

169

170

171

172

173

174

175

176

177 operators have rallied to rebut criticism and improve animal welfare practices (AMMPA, 2013; SeaWorld, 2013; Lange, 2016)

There is varying public opinion towards visiting captive cetacean attractions. Industry polls in 1992 and 2005 found, respectively, that $89 \%$ and $97 \%$ of the general public thought aquaria (including MMPs and SWTD attractions) were important educational venues (AMMPA, 1992; AMMPA, 2005). Jiang et al. (2007) also stated that the majority of visitors to an MMP knew of educational opportunities and felt better-educated. Additionally, the 1992 survey found that 37\% of respondents believed captivity to be detrimental to animal life spans (AMMPA, 1999). A 2003 Canadian poll, reported originally by Zoocheck (see Jiang et al., 2007), and a 2014 US one showed public opposition to cetacean captivity at $68 \%$ and $50 \%$, respectively (Jiang et al., 2007; Edge Research, 2014). Whale-watching eco-tourists in Belize identified $96 \%$ opposition to the capture of dolphins, $78 \%$ opposition to keeping them in closed tanks, and 67\% opposition to keeping them in open-sea pens (Patterson, 2010). A study in Aruba identified that only $35 \%$ of tourists would be as comfortable seeing dolphins in captivity as in the wild (Luksenburg \& Parsons, 2014). Of tourists surveyed in the Dominican Republic, $70 \%$ had no plans to visit a captive dolphin facility (Draheim, Bonnelly, Bloom, Rose, \& Parsons, 2010). In a 2004 survey of Canadian residents, the most common reasons given for not visiting captive cetacean attractions were lack of interest, high admission costs, and animal welfare issues. Respondents who visited these attractions cited the performances and educational opportunities, rather than human-animal contact, as their motives. Half of the visitors were knowledgeable of associated animal welfare issues, but few were aware of conservation concerns (Jiang et al., 2007).

With such variable snapshots of public opinion on cetacean captivity, further studies are needed to more clearly inform attraction developers, cetacean conservationists, animal welfare advocates, and policy-makers. It has been suggested that these studies need to particularly address the introduction of bias in public opinion research on cetacean captivity, as previous research has often been seen as expending little or ineffective effort on the issue (Marino, Lilienfeld, Malamud, Nobis, \& Broglio, 2010). We used a photo elicitation approach to research the opinions of tourists in the Turks and Caicos Islands (TCI) toward developing and visiting captive cetacean attractions. We also sought to gain insight on the lack of consensus in previous research on public opinion of cetacean captivity. Through using a methodological approach known for reducing the introduction of some forms of bias, we aimed to contribute to an accurate and up-to-date baseline of public opinion on cetacean captivity.

\section{Study Site}

The TCI are an archipelago nation of approximately 40 islands (see Figure 1) in the Caribbean region. With a growing population of 31,458 in 2012 (Turks and Caicos Islands Government [TCIG], 2012a), the tourism sector was responsible for at least $41.8 \%$ of Gross Domestic Product 
178 (GDP) in 2011 (TCIG, 2012b). Of the 1,315,268 tourists who visited the TCI in 2015, 70.7\% 179 visited the island of Grand Turk on cruise ships and most of the remaining 385,531 based their 180 stopover ${ }^{1}$ vacations on Providenciales (Turks and Caicos Tourist Board [TCTB], 2015). Tourism 181 has grown near year-on-year since at least the 1990s, a trend likely to continue (TCTB \& 182 Department of Economic Planning and Statistics [DEPS], 2009; TCIG, 2012b). The TCI 183 Government (TCIG) encourages the development of attractions that will encourage further tourism 184 (TCIG, 2012b), but states that any industries supporting economic expansion should be 185 "economically, culturally, socially and environmentally sustainable" (Ministry of Finance Trade 186 and Investment, 2013).

Cetacean captivity was prohibited in the TCI until a 2012 legal amendment to the Fisheries Protection Ordinance (1998), made to accommodate the development application for two proposed SWTD attractions ('Protests in TCI', 2014). This amendment was protested by environmental NGOs and the nation's Department of Environment and Marine Affairs (DEMA), highlighting conservation and animal welfare concerns (Tyson, 2013; House of Commons Environmental Audit Committee, 2014; 'Protests in TCI' 2014). However, TCI policy-makers continued to back development, based on support from TCI citizens who hoped the facility would bring employment and on developer guarantees that the attractions would be especially popular with tourists from the US ('Dolphin Cove development', 2014; 'More jobs', 2014; 'Protests in TCI' 2014; Tyson, 2014). Most cruise ship passengers and 81.7\% of stopover guests in 2015 were US citizens (TCTB, 2015).

At the time of data-collection, the TCI SWTD attractions remained proposed but not constructed. The only existing tourism associated with cetaceans was small-scale whalewatching tours from Salt Cay. These tours did not ordinarily involve cruise ship tourists or Providenciales stopover guests (Visit Turks \& Caicos Islands, 2017).

\section{Materials \& Methods}

Several types of bias can be present in public opinion surveys (see Table 1). Many of the previous studies of public opinion of cetacean attractions were conducted by researchers with their own opinions of cetacean captivity. While personal interest is a valid reason to conduct research (Bennet, Ekinsmyth, \& Shurmer-Smith, 2002), certain methods are inherently prone to researcherintroduced bias, even when the researcher is careful to avoid it. It was important for us, who ourselves identified as anti-captivity, to design a study that was as free of researcher bias as possible.

To avoid introducing potential conditioned bias developed through exposure to the intense local debate over the conservation, animal welfare, and job-creation issues surrounding the development of the two local SWTD attractions, foreign tourists, rather than TCI residents, were chosen as respondents. In addition, the opinions of tourists are perhaps the most important when

\footnotetext{
${ }^{1}$ A 'stopover' tourist is defined as one who spends 24 hours or more at their resort destination.
} 
217 considering the justification for developing an SWTD attraction, as they will provide the 218 attendance (or otherwise) that make it viable. Motivated, ingratiation, and social desirability bias 219 were minimised by designing a survey instrument that initially concealed the primary focus of the 220 research from the respondent. Open-ended response options were favoured to minimise the chance 221 introduction of various researcher biases during survey design. Open-ended responses preclude 222 the collection of inaccurate data when respondents are forced to choose one closed option when

223

224

225

226

227

228

229

230

231

232

233

234

235

236

237

238

239

240

241

242

243

244

245

246

247

248

249

250

251

252

253

254

255

256 they would rather choose multiple (Zaller \& Feldman, 1992).

Our survey team first showed respondents a grid of six photographs (Fig. S1). These depicted six tourist attractions not present in the TCI, but that were popular elsewhere in the Caribbean region, according to feedback on the review website TripAdvisor. When shown the photographs, respondents were asked: "What are your opinions on any of these six attractions being introduced in the Turks and Caicos Islands?" This simple question did not introduce our own opinions or prior knowledge, and therefore personal bias, on any of the conservation, educational, entertainment, welfare or other issues associated with the attractions. No closed options were provided and respondents were not forced to comment on each photograph. Showing the six photographs simultaneously reduced bias associated with presentation order (Gibson et al., 2014). Surveyors took notes on the qualitative comments volunteered by respondents.

Photo elicitation has an excellent track record for accessing the true worldview of respondents (Harper, 2002), as it hands the role of dialogue construction, or the "voice of the research", to the research participant (Frith et al., 2005). Rather than taking verbal cues from the language used in researcher-designed questions, participants can reflect on what an image means to them in their own words. They may pick up on entirely different themes in a photograph than those that a researcher might expect (Epstein et al., 2006). Yet, photo elicitation can still introduce bias, potentially motivated, when researchers do not theoretically account for variables between photographs (Gaber \& Gaber, 2004). We justified its selection because it removed many further opportunities for insertion of researcher-induced bias and we took a theoretical approach to photograph selection to minimise introduction of our personal biases. Elimination of all variables in the images (e.g. the prominence of human subjects across all images) would not have accurately represented these attractions, nor likely have been possible. Therefore, we chose photographs from our personal collections and Creative Commons sources that best represented the perspectives, scenes, and human behaviour evident in a standard Google Images search for each attraction. Previous studies using vision-based approaches to selecting representative images have also used criteria such as the frequency of photographs depicting a scene and of the subject attention and behaviour represented (Kennedy et al., 2007). For example, the top 100 results returned for "swimwith-the-dolphins" included 81 close-ups of individuals swimming with captive dolphins, with 73 of those individuals facing the camera and clearly smiling. To further ensure internal validity, attractions were also named orally by our survey team when shown to the respondents, ensuring that focus was more likely to remain on the attraction.

After showing respondents the image grid, our surveyors asked, on a 4-point Likert scale, whether they would be "very unlikely", "unlikely", "likely" or "very likely" to visit such an 
257

258

259

260

261

262

263

264

265

266

267

268

269

270

271

272

273

274

275

276

277

278

279

280

281

282

283

284

285

286

287

288

289

290

291

292

293

294

295

attraction in the TCI. If we had asked these intention-orientated questions first, it is more likely that respondents would have only volunteered opinions to our open question that were aligned with their chosen closed response. Inclusion of a neutral option between "unlikely" and "likely" was considered but rejected, as we wanted to avoid potential social desirability bias causing respondents to choose uncontroversial options (Garland, 1991). The survey team were trained to ask questions in a neutral manner. They were also asked to avoid wearing clothing that might introduce ingratiation bias (e.g. t-shirts with anti-captivity or pro-conservation logos). Finally, respondents were asked demographic questions about their age, gender, country of residence, accommodation, and experience with and interest in cruise tourism.

We used a consecutive sampling approach (see Lunsford \& Lunsford, 1995) to complete a total of 292 daytime surveys with stopover tourists on Grace Bay Beach, Providenciales on 18 March 2014. With 292 respondents, we estimate the overall margin of error $(95 \%$ confidence interval) to be $\pm 5.7 \%$, and results with confidence bounds that did not cross $50 \%$ were concluded to be "likely" or "unlikely" depending on the extent of their boundaries. As we had a large survey team, we could approach every visible tourist on the beach, with the exception of those engaged in activities that impeded their participation (e.g., swimming, sleeping). Respondents were told before they took the survey that their participation was optional and all who consented were enrolled. During the day, the great majority of Providenciales tourists are found on Grace Bay beach or in their resorts. As access to resorts is generally prohibited, this was as complete and representative sample of the target population as could be realistically achieved. This approach reduced the sample bias in previous surveys of public opinion on cetacean captivity, where less strict formats of convenience sampling have been employed (Marino et al., 2010). Surveying in Grand Turk was not logistically possible, but we asked Providenciales visitors about their preference for cruise tourism to gauge the possible attitudes of the cruise ship passengers who visit Grand Turk.

Statistical analyses were conducted using R (R Core Team, 2015) and Prism. As the Likert scale used did not assign numerical values, we used non-parametric Chi-Square tests to assess hypotheses of difference. For testing the summary responses for each attraction, we used all four Likert variables. For testing on demographic variables, we condensed the responses to two groups, "likely" ("very likely" and "likely" responses) and "unlikely" ("very unlikely" and "unlikely" responses), to facilitate significance testing. We performed tests on a variable if there were large enough groups of individuals for detecting significance, defined here as greater than five individuals. We used Bonferroni corrections within the demographic subgroups (2-7 categories) and significance level is reported for the corrected p-value.

We used structural coding, as described by Saldaña (2013), to code surveyors' notes of respondents' qualitative responses. These were coded as either "NEGATIVE OPINIONS OF MMPs" and "NEGATIVE OPINIONS OF SWTD ATTRACTIONS", or "POSITIVE OPINIONS OF MARINE MAMMAL PARKS" and "POSITIVE OPINIONS OF SWTD ATTRACTIONS". No neutral responses were expressed by respondents, so we did not include a neutral coding 
296

297

298

299

300

301

302

303

304

305

306

307

308

309

310

311

312

313

314

315

316

317

318

319

320

321

322

323

324

325

326

327

328

329

330

331

332

333

334

335

descriptor. We also conducted subcoding of the reasons for opinions where possible. We recorded the number of respondents expressing each opinion.

We followed all legal and ethical guidelines for conducting research in the TCI. We did not ask for personal identifiers during surveys, nor were they recorded if given. No individuals from vulnerable populations were enrolled. Verbal consent was acquired. Although the focus of research was initially concealed during survey administration to avoid introducing motivated, ingratiation, and social desirability biases, the true focus of the research (i.e. to measure public opinion of captive cetacean attractions) was revealed to respondents following their participation. No respondents subsequently withdrew their participation when the option was again offered.

\section{Results}

\section{Sample demographics}

There were a total of 292 respondents and all responses were voluntary. Respondents were $61.1 \%$ female and $38.9 \%$ male $(\mathrm{n}=280)$. By age, $15.2 \%$ of respondents were $18-29$, with $10.5 \%$ being $30-39,31.0 \%$ being $40-49,23.1 \%$ being $50-59$, and $22.2 \%$ being 60 or older $(n=277)$. Most respondents resided in North America, with $71.5 \%$ living in the US and $25.8 \%$ in Canada. The remaining 2.8\% were from Europe, South America, and Egypt $(n=291)$. Where $n<292$, it is due to non-responses, all of which are reported in Table 2.

In terms of tourists' preferences, those who would consider a future cruise vacation comprised $37.8 \%$, with the remainder uninterested $(n=288)$. Of the tourists surveyed, $39.8 \%$ were staying in all-inclusive resorts, which provided activity programmes as part of the package, with the remainder staying in other accommodation $(\mathrm{n}=289)$. Across the sample, $47.4 \%$ had vacationed in the TCI more than once $(n=289)$.

\section{Qualitative responses: rate and nature}

Very few respondents offered qualitative responses for all six photographs. For the photograph of the SWTD attraction, $26.4 \%$ of respondents provided open-ended responses, with this reduced to $18.2 \%$ for the MMP killer whale show. While a small number of respondents responded in greater detail, most answers were between one and three sentences long. All qualitative responses were about the featured attractions, rather than comments that could only be attributed to the images themselves; no respondent remarked on the child in the SWTD image (Fig. S1).

\section{Overall perceptions of tourists}

Respondents favoured the possibility of visiting a potential SWTD attraction over an MMP killer whale show, with an overall median description of "likely" to visit the SWTD attraction compared 
336

337

338

339

340

341

342

343

344

345

346

347

348

349

350

351

352

353

354

355

356

357

358

359

360

361

362

363

364

365

366

367

368

369

370

371

372

373

374

375

to "unlikely" for the MMP killer whale show. There was a significant difference $(\mathrm{p}<0.001)$ between the responses for the MMP killer whale show and the SWTD attraction. The preferred favourability rankings are SWTD attraction, aquarium, botanical gardens, craft market, MMP killer whale show, and maritime museum. The SWTD attraction, aquarium, and botanical gardens all had median descriptors of "likely" to be visited, with the MMP killer whale show and maritime museum having median descriptors of "unlikely". The craft market fell into its own significant group between "likely" and "unlikely". There was no significant difference between the SWTD attraction and the aquarium or botanical gardens, but there was a significantly higher likelihood to visit an SWTD attraction than a craft market $(\mathrm{p}<0.01)$. The MMP killer whale show was significantly less attractive than the three "likely" attractions $(p<0.001)$ and the maritime museum $(p<0.05)$, but not significantly less than the craft market. The full range or Likert responses for each attraction are reported in Table 3, with significant groupings shown in Fig. 2.

Only five respondents who were "likely" or "very likely" to visit an MMP killer whale show gave qualitative feedback, all stating "entertainment" as their reason for wanting to visit. The $4.2 \%$ of those "likely" or "very likely" to visit and who provided qualitative feedback said that though they were disinclined to visit themselves, they would be likely to visit an MMP killer whale show because it would be entertaining for their children. For those "unlikely" or "very unlikely" to visit, and who offered qualitative comments $(\mathrm{n}=48)$, the most frequently-given reasons were animal welfare concerns $(72.9 \%)$, perceived over-commercialisation of the attraction $(14.6 \%)$, and lack of entertainment (10.4\%). Their qualitative justifications for their decision-making included the belief that animals were being "abused" in such parks, that "animals [did not] belong in an environment like this", that they did not like the nature of performances, and that they objected to animals being "caged up". Respondents noted that there "was a lot of bad press" about killer whale shows and that Blackfish was "really sad". The documentary was cited by $14.6 \%$ of those "unlikely" or "very unlikely" to visit an MMP attraction and who gave qualitative responses for their reasoning for non-visitation. One respondent noted that their young daughter had told them the documentary showed abuse of killer whales. Only $4.2 \%$ of the same "unlikely" group, who provided qualitative responses, explicitly mentioned the human welfare threat to animal trainers as a reason for non-visitation.

For tourists offering qualitative appraisals that they would be "likely" or "very likely" to visit an SWTD attraction $(n=26)$ the only reasons they gave were entertainment value $(96.2 \%)$ and/or that it would be especially enjoyable for children (34.6\%). They made comments such as that their daughter would love it because she was going to a marine biology camp and that they had done it before in the Bahamas and would do it again. However, 15.4\% of this group mentioned that they knew about the related animal welfare concerns. The only respondent to mention Blackfish when commenting on the SWTD attraction stated the attraction remained "awesome" despite what he had seen in the documentary.

Among survey respondents "unlikely" or "very unlikely" to visit an SWTD attraction (n = 51) and who provided qualitative feedback, the three dominant reasons for their choice were animal welfare concerns $(56.9 \%)$, lack of entertainment value $(21.6 \%)$, and human welfare 
376 concerns (9.8\%). Qualitative feedback included statements that they would only swim with wild 377 dolphins, that "dolphins should be free", that their daughter had experienced a skin infection after 378 her human-dolphin interaction at another SWTD attraction, that they were worried about male 379 dolphins "getting frisky", and that they would rather go to the beach. Of this group, despite their 380 own opposition to the attraction, $11.8 \%$ said they would visit with children, as it was more 381 entertaining for that age group. One tourist said she was "unlikely" to visit this type of attraction 382 again, but she "loved it" when she did it before. No respondents mentioned The Cove in the 383 unprompted qualitative feedback. A summary of all qualitative responses is detailed in Table 4.

384

385

386

387

388

389

390

391

392

393

394

395

396

397

398

399

400

401

402

403

404

405

406

407

408

409

410

411

412

413

414

415

By accommodation type

Tourists staying in all-inclusive resorts were significantly more "unlikely" to visit a potential SWTD attraction than respondents in other accommodations $(p<0.001)$. Those staying in allinclusive resorts were also significantly less interested in visiting MMP killer whale shows $(\mathrm{p}<$ 0.001 ). For this variable, and those that follow, a more detailed summary of tourist visitation likelihood is found in Table 5 .

By age

Interest in SWTD attractions decreased with age, with older participants more "unlikely" ( $\mathrm{p}<$ 0.001 ) to visit. There were no significant differences for MMP killer whale shows on this criterion.

By country of residence

Significant groupings $(\mathrm{p}=0.001)$ were reported for preference toward visiting an SWTD attraction. Respondents from the US were the most positive and were "likely" to visit, compared to Canadians who fell between "likely" and "unlikely", and those from other countries who were generally "unlikely" to visit. After the Bonferroni correction, no significant differences were found between tourists from different countries for visiting the MMP killer whale show.

\section{By gender, parental status, preference for cruise tourism, and trip frequency to TCI}

There were no significant differences in interest in SWTD attractions or MMP killer whale shows by gender, parental status, preference for cruise tourism, or frequency of visitation to the TCI.

\section{Discussion}

Public opinion of SWTD attractions 
416 A majority of tourists to the TCI supported the introduction of an SWTD attraction. The figure of 417 support (60.3\%) was, however, below the 70.2\% found in an earlier industry survey (AAMPA, 418 2005). The reason for support in our study was overwhelmingly that such an attraction would be 419 entertaining, with some respondents specifically mentioning their children's potential interest. The 420

421

422

423

424

425

426

427

428

429

430

431

432

433

434

435

436

437

438

439

440

441

442

443

444

445

446

447

448

449

450

451

452

453

454

455 earlier, higher figure came from a study that potentially introduced motivated bias by asking respondents to agree or disagree with the statement: "I would be interested in swimming with dolphins in a safe, legal and permitted environment at a marine life park, aquarium or zoo" (AAMPA, 2005). The figure found in our study was also above the percentages found in several previous public opinion studies of tourists, where majorities of respondents reported not favouring visiting captive dolphin attractions (Draheim et al., 2010; Luksenburg \& Parsons, 2014). The demographics of our participants were similar to Luksenburg \& Parsons (2014), where 59\% of tourists surveyed in Aruba were from the USA. It is possible that, despite Luksenburg \& Parsons' best efforts to avoid bias, their use of extensive closed-questioning introduced motivated, ingratiation, and/or social desirability bias.

Alternatively, the differences between the findings from these studies and ours may be due to the sampling locations and approaches. Draheim et al. (2010), Luksenburg \& Parsons (2014), and ourselves all surveyed tourists, but in different resorts. Visitors to different locales can have different attitudes, as is the case for tourist perceptions of the natural environment, which differ by island in the Caribbean region (Uyarra et al., 2005). Our study is also less comparable to Miller (2013), where visitors to a captive marine mammal attraction were surveyed while in attendance or Patterson (2010), where the surveys were conducted with volunteers for a high-end whale watching and eco-tourism outfit. These studies sampled sections of the public predisposed to visiting cetacean attractions, while our study sampled a section of the general public for whom no predisposition towards or against visiting captive cetacean attractions can be assumed.

While previous research has cited education, conservation, and welfare benefits as the reasons the public give for visiting captive cetacean attractions, in this study, the only motivation mentioned by respondents for visiting SWTD attractions was their entertainment value. This suggests that the polls that found that at least $80 \%$ of respondents see educational and conservation values in captive cetacean attractions have over-asserted these attitudes (e.g. AMMPA, 2005; Miller et al., 2013). This difference may be due to potential ingratiation bias in the survey by Miller et al. (2013), where statements like "this experience was educational" were put to respondents while they were visiting the attraction. It would be uncomfortable for a respondent to respond negatively to this statement while talking to a surveyor they might suspect has a working relationship with the attraction. Jiang et al. (2007) similarly found that conservation value was not greatly attached to captive cetacean attractions by visitors, but even their paper, openly sceptical of the educational value of such attractions, still found that visitors offered education as a reason for their attendance. Jiang et al. (2007) also specifically asked about education opportunities, which might have introduced motivated bias through the survey questions, as a result of leading respondents to assign more weight to an issue than they might have independently. We expect that researchers seemingly sceptical of a perceived value to the public would not intentionally insert 
456 bias that caused that value to be highly reported by respondents, illustrating how hard it can be to 457 design written, closed questions that do not influence the participant. Additionally, the benefits to 458 human health claimed in some research may not be a valid reason for maintaining and developing 459 SWTD attractions, as respondents in our research only identified associated threats to human well460 being from visiting such attractions.

461

462

463

464

465

466

467

468

469

470

471

472

473

474

475

476

477

478

479

480

481

482

483

484

485

486

487

488

489

490

491

492

493

494

Furthermore, $39.7 \%$ of tourists surveyed here were not in favour of visiting SWTD attractions, primarily citing dolphin welfare concerns, where reasoning was provided. These viewpoints cast doubt on the interpretations of the AMMPA (2005) survey, where AMMPA stated that the general public believed animal welfare was high at such attractions. In that survey, $95 \%$ agreed that "the people who care for the animals at marine life parks, aquariums and zoos are committed to the welfare of the animals" (AMMPA, 2005), a question more focused on the capability of the trainers than the condition of captive animals. The wording likely introduced the motivated bias of the researchers. Our results are closer to those made by Jiang et al. (2007) in Canada, where a major reason for non-visitation was animal welfare concerns.

In our study, overall opposition to an SWTD attraction was noted for those staying in allinclusive accommodation, tourists residing outside of the US and Canada, and older adults. The lack of appropriate qualitative data offered by most respondents makes it hard to fully explain their opposition. Whatever their reasoning, the opinions of these demographic groups have implications wherever they are present. All-inclusive tourism models are particularly popular in the Caribbean (Brida \& Zapata, 2010), with just above 50\% of its tourists not from the US (Caribbean Tourism Organization, 2014), and the average age of visitors from the US being over 40 (International Trade Administration, 2014). All-inclusive resorts provide entertainment for their guests, and for countries like the TCI, where these resorts are among the biggest individual employers (Allen, 2013), there are limits to the market for SWTD attractions.

In general, TCI tourists were willing to visit an SWTD attraction, even when aware of the associated animal welfare concerns amplified in recent media. Jiang et al. (2007) also found this to be the case among the Canadian public. Researchers and advocates opposing dolphin captivity may still see an opportunity to influence public opinion, however, in the relatively low level of human welfare and dolphin conservation concerns recorded in this study. Draheim et al. (2010) noted that tourists in the Dominican Republic were similarly unaware of welfare and safety concerns, with $75 \%$ of their sample not seeing swimming with dolphins as dangerous. Their study also found that, when required to provide a closed answer, over $80 \%$ of tourists placed weight on dolphin conservation issues. Without prompting from close-ended survey questions, dolphin conservation was barely identified as an issue by TCI tourists. If this was due to a lack of awareness rather than apathy, then there is potential to increase public knowledge of both conservation and welfare issues.

\section{Low public opinion of MMP killer whale shows}


495 TCI tourists' overall attitude toward MMP killer whale shows was largely negative. The $60.9 \%$ 496 who identified as not likely to visit such attractions roughly correlates to a recent survey where 497 closed-ended questions found $50 \%$ of a sample of the general public opposed killer whale captivity 498 (Edge Research, 2014). It is possible that, because of their use of telephone interviews conducted 499 by professional surveyors, the surveyors managed to reduce some ingratiation and social 500 desirability bias (Rossiter, 2009). There is also the possibility that motivated bias introduced 501 through question design had a lesser impact, as public opinion of killer whale captivity in MMPs 502 was already strongly formed, possibly due to exposure to more media on the welfare of captive 503 killer whales than captive dolphins.

504

505

Tourists not staying in all-inclusive resorts were the only respondent demographic to clearly identify as positive towards visiting an MMP killer whale show, but there were not enough

506

507

508

509

510

511

512

513

514

515

516

517

518

519

520

521

522

523

524

525

526

527

528

529

530

531

532

533

534 qualitative responses to explain why. Of the reasons given, the strongest concern was for animal welfare. Education, conservation, and human welfare benefits were not cited as reasons for wanting to visit. Conservation concerns were not mentioned as a deterrent. Again, this contrasts with previous surveys that may have introduced pro- or anti-captivity researcher-motivated bias through their use of close-ended questions, such as those that have found a wide range of respondent agreement (56-97\%) that these attractions offer educational experiences (e.g. AMMPA, 2005; Jiang et al., 2007; Edge Research, 2014).

Media influence had noticeably more impact on respondents' opinions of MMP killer whale shows than SWTD attractions, with several citing having watched Blackfish as their reason for not wanting to visit such an attraction. This influence is supported in the results of a recent survey, which showed that $73 \%$ of the US public learned about killer whales via the media (Edge Research, 2014). It is also reflected in the dramatic fall in the stock market value of North America's primary provider of killer whale attractions, which has been blamed on negative publicity and resultant decreasing visitor numbers (Peterson, 2014; Huggan, 2017). In 2016, the same provider announced the end of their captive breeding programme and therefore the eventual end of captive killer whale shows at their attractions (Hacket, 2016). However, while the documentary extensively covered the human welfare issues associated with training killer whales, TCI tourists' qualitative responses rarely explicitly identified these issues, even when mentioning Blackfish.

\section{Shifting public opinion of SWTD attractions and MMP killer whale shows}

The issues contributing to the public opinion of dolphin and killer whale captivity are similar, yet the respondents here were more likely to visit SWTD attractions than MMP killer whale shows. In the qualitative responses, media influence was cited less frequently for SWTD attractions as a factor in potential visitation. The showing of Blackfish on well-watched television outlets is credited for broadening the media profile of the negative issues associated with MMP killer whale shows, especially given the deaths of trainers highlighted in the film (Huggan, 2017; Parsons \& Rose, 2018). 
535

536

537

538

539

540

541

542

543

544

545

546

547

548

549

550

551

552

553

554

555

556

557

558

559

560

561

562

563

564

565

566

567

568

569

570

571

572

573 The relatively low qualitative response rate from participants impeded our ability to explain the 574

A similar shift in public opinion could be expected if a member of the public were seriously harmed at an SWTD attraction (Hunt et al., 2008; Rose et al., 2009). Indeed, shifts in public opinion have already been credited for the closures of the last United Kingdom captive dolphin attractions in the 1990s (Hughes, 2001) and a facility in the Bahamas in 2014 (Lowe, 2014). Pushback against a plan to construct an SWTD attraction in Arizona, USA led to a petition with over 170,000 signatures (Milman, 2016; Dee, n.d.). In these cases, dolphin welfare has primarily driven public opinion, though recent opposition has cited bites from dolphins and "incidents that resemble sexual assault" (Milman, 2016). Nevertheless, the captive cetacean industry continues to invest in infrastructure and propose new attractions. Approximately 25 additional SWTD attractions have been proposed for the Caribbean region (Rose et al., 2009), including the two in the TCI. Policy-makers, governments, and tourist attraction developers need to be aware of potential negative shifts in public opinion of SWTD attractions, as they would likely cause the same drop in visitation as for MMPs.

Our results could also be interpreted as the public believing that dolphin welfare in SWTD attractions is higher than for killer whale welfare in MMPs. Yet, this interpretation is actually contrasted by our qualitative data which suggest that dolphin welfare is not at the forefront of public consciousness. Very few of our participants commented on captive cetacean welfare and those that did mentioned killer whale captivity rather than that for dolphins. Either the public care less about the welfare of captive dolphins than of killer whales, perceive dolphins to be bettersuited to captivity, leading to better welfare, or have not been as exposed to the welfare issues surrounding dolphin captivity. Our study lacks the data necessary to determine which scenario is most likely and further research is necessary to determine the root of the lack of public consciousness over dolphin captivity.

\section{Alternatives to captive cetacean attractions}

Aquariums and botanical gardens, rated by TCI tourists as significantly more desirable than MMP killer whale shows and similarly desirable to SWTD attractions, have been shown to provide educational and conservation value (Parsons \& Muhs, 1994; Falk \& Adelman, 2003; He \& Chen, 2012), with less debate than for captive cetacean attractions. Where possible, wild whale and dolphin-watching tours may be better attractions to endorse as they have, in some studies, been found to have fewer negative conservation and animal and human welfare issues (Jiang et al., 2007). Research in Aruba (Luksenburg \& Parsons, 2014), the Dominican Republic (Draheim et al., 2010), and Belize (Patterson, 2010) has shown that visitors would prefer wild cetacean encounters to captive ones.

\section{Advantages and limitations of the photo elicitation methodology}

respondents' reasoning behind their quantitative Likert ratings. All the other public opinion studies 
575 of captive cetacean attractions reviewed here did draw specific conclusions about whether 576 entertainment, educational or conservation value, or human or animal wellbeing were reasons for 577 visitation or non-visitation, because they received a complete response rate to their worded, closed 578 questions. Yet, we know these worded questions can also be limited, likely more so, due to the 579 opportunities for introducing bias that distorts responses. In some cases, it might be easier to write 580 more neutral closed survey questions, but with emotionally-sensitive topics like animal captivity 581 and welfare, it is difficult. The benefit of photo elicitation is that it leaves the respondent open to 582 responding how they want to, decreasing potential bias.

583

584

The results of this study, for instance, do not reveal whether TCI tourists believed an SWTD attraction would be educational or improve their wellbeing, or otherwise, but this

585

586

587

588

589

590

591

592

593

594

595

596

597

598

599

600

601

602

603

604

605

606

607

608

609

610

611

612

613

614 ambiguity can be valuable. The lack of definitive qualitative findings from respondents on the potential educational, conservation, and human wellbeing benefits of SWTD attractions, or of animal and human welfare issues, is because the respondents guided this research. Many of the issues previously highlighted by researchers were simply not at the forefront of TCI tourists' minds when considering which attractions they would like to visit. Conclusions drawn elsewhere, therefore, may have been influenced by researcher-introduced bias, preventing a true snapshot of public opinion. While the lack of qualitative responses to photo elicitation limits the explanatory power of our quantitative findings, the responses that were elicited, especially on the entertainment value of SWTD attractions, do begin to explain our data. Follow-up research, attempts at replication, and comparative case studies should look to elicit more extensive open-ended responses from participants. These could use an approach that compels a comment for each photograph, as long as care was still taken to avoid introducing researcher bias.

One success of this methodology was not initially revealing the full research aims to respondents, reducing bias. The substantial differences between the opinions of TCI tourists on cetacean captivity and those found in several similar surveys is likely down to our accounting for the biases listed in Table 1. Many of the other surveys did not describe attempts to reduce these biases. Yet, our selection of photographs may have remained an issue. The photographs used in this approach, though carefully selected with a theoretically-grounded approach, could have inherently influenced respondents. The image used for the SWTD attraction (Fig. S1), for instance, is a close-up of a child smiling while swimming with a dolphin, while the image for the MMP killer whale show (Fig. S1) is a more distant photograph with the faces of spectators out of focus. As photographs with smiling subjects tend to indicate positive experiences (Miles \& Johnston, 2007), the SWTD attraction image is more likely to have attracted additional positive responses, irrespective of general opinions of the attraction, and perhaps has artificially inflated our figure for respondents' likelihood to visit SWTD attractions. No respondents commented on the image content (Fig. S1), however, suggesting this was likely not a major issue here. Still, bias introduction through photograph selection cannot be ruled out. Further photo elicitation studies on the influence of photographs of subjects with varying expressions, or photographs where facial expressions were not shown, would give further context to the value of the quantitative results presented here. To more definitively determine the strengths and limitations of the photo elicitation 
615 methodology, a follow-up study comparing photo elicitation in parallel to traditional survey

616 methods would be useful.

617

618

619

620

621

622

623

624

625

626

627

628

629

630

631

632

633

634

635

636

637

638

639

640

641

642

643

644

645

646

647

648

649

650

651

652

653

654

\section{Conclusions}

There is no consensus on public opinion of captive cetacean attractions. Underestimation of unintentional researcher bias in study design and of probable attempts to deliberately guide respondents toward the outlooks of those conducting or commissioning research has led to a spectrum of reported opinion. For this study, we selected a photo elicitation approach and attempted to account for all forms of bias. Our findings suggest that previous claims of public support for MMP killer whale shows have likely been overstated, as have assertions of both opposition to and support for SWTD attractions. While the photo elicitation approach employed here has its own limitations, the method avoids the insertion of the most severe researcher-driven biases and hands the initiative for evidence production on public opinion of captive cetacean attractions to the public themselves. Policy-makers and developers should not base their decisions on licensing and building captive cetacean attractions on the outcomes of public opinion studies without scrutinising the validity of how public opinion was surveyed.

Researcher-introduced bias seems to have been a particular issue in over-assigning some values of captive cetacean attractions to the public. The lack of respondent comments on the educational or conservation value of captive cetacean attractions suggests previous studies have erroneously introduced these as major issues of public focus through inserting survey questions on these issues. With some of these values disputed by researchers, there is a case for giving less weight to them as factors in decision-making on the development of captive cetacean attractions. Their entertainment value, which here was already diminished for MMP killer whale shows, could diminish for SWTD attractions if the public becomes concerned with the conservation, animal welfare, and human welfare issues associated with such facilities. There would seem little longterm public value to captive cetacean facilities and their further development should perhaps be reconsidered.

Ultimately, all involved in proposing or opposing cetacean captivity require a better baseline of public opinion toward MMP killer whales shows and SWTD attractions. Future research must involve a greater effort to address methodological biases. This can be achieved through mixed-methods approaches that still allow researchers to quantitatively assess the elements of public opinion they are interested in, but which first permit respondents to provide qualitative feedback using their own voice. The photo elicitation approach used here was partially successful in doing this, but was limited by the number of qualitative response it fostered. Best practice might be to follow a similar approach, but ask additional, neutral open-ended questions at the start of the survey, or to compliment it with other qualitative approaches (e.g. interviewing) that allow a more in depth investigation of quantitative findings. 
655

656

657

658

659

660

661

662

663

664

665

666

667

668

669

670

671

672

673

674

675

676

677

678

679

680

681

682

683

684

685

686

687

688

689

690

691

692

693

\section{Acknowledgements}

We gratefully acknowledge the key logistical support provided by The School for Field Studies (SFS) Center for Marine Resource Studies. We are also thankful to Dr. Chris Parsons, Dr. Naomi Rose, and Peter Craig for their extremely helpful comments on previous drafts of this transcript, as well as to a number of anonymous reviewers. We thank Morag Taite for her ArcGIS expertise in constructing Figure 1. Finally, we are indebted to the students of The SFS Center for Marine Resources Studies Spring '14 Program who did an excellent job conducting the surveys. This research project would not have been possible without their participation, diligence, professionalism, and dedication.

\section{References}

Actman, J. (2017, March 17). China's First Orca Breeding Center Sparks Controversy. National Geographic. Retrieved from https:/news.nationalgeographic.com/2017/03/wildlifewatch-china-orca-breeding-center-marine-park/

Allen, D. (2013, March 17). Beaches resort a key element of Turks and Caicos economy. Jamaica Observer. Retrieved from http://www.jamaicaobserver.com/news/Beachesresort-a-key-element-of-Turks-and-Caicos-economy--says-governor_13877632

Alliance of Marine Mammal Parks and Aquariums. (1999). Fact book on marine mammals. Alexandria, USA: Alliance of Marine Mammal Parks and Aquariums.

Alliance of Marine Mammal Parks and Aquariums. (2005). Marine mammal poll. Retrieved from http://www.ammpa.org/_docs/HarrisPollResults.pdf

Alliance of Marine Mammal Parks and Aquariums. (2013). Annual Report 2013. Westminster, USA: Alliance of Marine Mammal Parks and Aquariums.

Antonioli, C. \& Reveley, M.A. (2005) Randomised controlled trial of animal facilitated therapy with dolphins in the treatment of depression. BMJ, 331.

Back, K. W., \& Gergen, K. J. (1943). Idea orientation and ingratiation in the interview: A dynamic model of response bias (Technical Report No. 13). Durham, USA: Duke University.

Ballantyne, R., Packer, J., Hughes, K., \& Dierking, L. (2007). Conservation learning in wildlife tourism settings: Lessons from research in zoos and aquariums. Environmental Education Research, 13, 367-383. DOI: 10.1080/13504620701430604 
694 Barney, E. C., Mintzes, J. J., \& Yen, C. F. (2005). Assessing knowledge, attitudes and behaviour

695

696

697

698

699

700

701

702

703

704

705

706

707

708

709

710

711

712

713

714

715

716

717

718

719

720

721

722

723

724

725

726

727

728

729

730

731

732 toward charismatic megafauna: The case of dolphins. The Journal of Environmental Education, 36, 41-55. DOI: 10.3200/JOEE.36.2.41-55

Bennet, K., Ekinsmyth, C., \& Shurmer-Smith, P. (2002). Selecting topics for study. In P. Shurmer-Smith (Ed.), Doing cultural geography (pp. 81-93). London, UK: SAGE.

Berk, R. A. (1983). An introduction to sample selection bias in sociological data. American Sociological Review 48, 386-398. Retrieved from http://www.jstor.org/stable/2095230

Born Free Foundation. (2018). Captive whales and dolphins - global. Retrieved from http://www.bornfree.org.uk/campaigns/zoo-check/captive-whales-dolphins/global/

Bossart, G. (2016) Beluga Import Project. Georgia Aquarium. Retrieved from http://news.georgiaaquarium.org/internal redirect/cms.ipressroom.com.s3.amazonaws.co $\mathrm{m} / 216 /$ files/20165/Beluga\%20Import\%20Project\%20Media\%20Kit.pdf

Brensing, K., \& Linke, K. (2003). Behavior of dolphins towards adults and children during swim-with-dolphin programs and towards children with disabilities during therapy sessions. Anthrozoos, 16, 315-331. DOI: 10.2752/089279303786992035

Brida, J. G., \& Zapata-Aguirre, S. (2010). Cruise tourism: Economic, socio-cultural and environmental impacts. International Journal of Leisure and Tourism Marketing, 1, 205226. DOI: 10.1504/IJLTM.2010.029585

Change for Animals Foundation. (2018). CFAF's Work for Whales and Dolphins in Captivity. Retrieved from http://www.changeforanimals.org/whales-and-dolphins-in-captivity

Clegg, I.L., Rödel, H.G., Boivin, X., \& Delfour, F. (2018) Looking forward to interacting with their caretakers: dolphins' anticipatory behaviour indicated motivation to participate in specific events. Applied Animal Behaviour Science, 202, 85-93.

Clegg, I.L.K., Van Elk, C.E., \& Delfour, F. (2017) Applying welfare science to bottlenose dolphins (Tursiops truncatus). Animal Welfare, 26, 165-176.

Clegg, I.L.K, Borger-Turner, J.L., \& Eskelinen, H.C. (2015). C-Well: The development of a welfare assessment index for captive bottlenose dolphins (Tursiops truncatus). Animal Welfare 24, 267-282.

Coldwell, W. (2014, September 12). Marine park attractions: Can they survive? The Guardian. Retrieved from http:/www.theguardian.com/travel/2014/sep/12/seaworld-blackfishmarine-park-attractions-future

Constantine, R. (2001). Increased avoidance of swimmers by wild bottlenose dolphins (Tursiops truncatus) due to long-term exposure to swim-with-dolphin tourism. Marine Mammal Science, 17, 689-702. DOI: 10.1111/j.1748-7692.2001.tb01293.x

Constantine, R., Brunton, D.H., \& Dennis, T. (2004). Dolphin-watching tour boats change bottlenose dolphin (Tursiops truncatus) behaviour. Biological Conservation, 117, 299307. DOI: 10.1016/j.biocon.2003.12.009

Cowperthwaite, G. (Producer/Director), \& Oteyza, M. V. (Producer). (2013). Blackfish [Motion picture]. USA: Manny O Productions. 
733 Curry, B.E., Ralls, K., \& Bronwell Jr., R.L. (2013) Prospects for captive breeding of poorly

734

735

736

737

738

739

740

741

742

743

744

745

746

747

748

749

750

751

752

753

754

755

756

757

758

759

760

761

762

763

764

765

766

767

768

769

770

771

772 known small cetacean species. Endangered Species Research, 19, 223-243.

Curtin, S. (2006). Swimming with dolphins: A phenomenological exploration of tourist recollections. International Journal of Tourism Research, 8, 301-315. DOI: $10.1002 /$ jtr.577

Curtin, S., \& Wilkes, K. (2007). Swimming with captive dolphins: Current debates and postexperience dissonance. International Journal of Tourism Research, 9, 131-146. DOI: $10.1002 /$ jtr.599

Dee, L. (n.d.). A Big "NO" to Captive Dolphins in Arizona! Retrieved from http://www.thepetitionsite.com/en-gb/234/874/624/a-big-\%22no\%22-to-captivedolphins-in-arizona/

Dijkstra, W. (1987). Interviewing style and respondent behavior: An experimental study of the survey-interview. Sociological Methods and Research, 16, 309-334. DOI: 10.1177/0049124187016002006

Dolphin Cove development to begin next year. (2014, June 30). Turks and Caicos Weekly News. Retrieved from http://tcweeklynews.com/dolphin-cove-development-to-begin-next-yearp5214-107.htm

Dougherty, S. D. (2013). The Marine Mammal Protection Act: Fostering unjust captivity practices since 1972. Journal of Land Use and Environmental Law, 28: 337-367. Retrieved from http://law-wss-01.law.fsu.edu/journals/landuse/vol28_2/dodson.pdf

Draheim, M., Bonnelly, I., Bloom, T., Rose, N., \& Parsons, E. C. M. (2010). Tourist attitudes towards marine mammal tourism: An example from the Dominican Republic. Tourism in Marine Environments, 6, 175-183. DOI: 10.3727/154427310X12764412619046

Edge Research. (2014). Findings from 2014 US National Survey on Orca Captivity. Retrieved from https://uk.whales.org/sites/default/files/edge_orca_poll_media_summary_may_2014.pdf

Epstein, I., Stevens, B., McKeever, P., \& Baruchel, S. (2006). Photo elicitation interview (PEI): Using photos to elicit children's perspectives. International Journal of Qualitative Methods, 5, 1-11. DOI: 10.1177/160940690600500301

European Association for Aquatic Mammals. (2016, March 19) EEAM Statement on Breeding of Cetaceans. Retrieved from https://eaam.org/statements/

Falk, J. H., \& Adelman, L. M. (2003). Investigating the impact of prior knowledge and interest on aquarium visitor learning. Journal of Research in Science Teaching, 40, 163-176. DOI: $10.1002 /$ tea. 10070

Fiksdal, B. L., Houlihan, D., \& Barnes, A. C. (2012). Dolphin-assisted therapy: Claims versus evidence. Autism Research and Treatment, 2012, Article ID 839792. DOI: $10.1155 / 2012 / 839792$

Fisher, S. J., \& Reeves, R. R. (2005). The global trade in live cetaceans: Implications for conservation. Journal of International Wildlife Law and Policy, 8, 315-340. DOI: $10.1080 / 13880290500343624$ 
773 Fisheries Protection Ordinance 1998 (TCI).

774 Friend, M. (2006). Disease emergence and resurgence: The wildlife-human connection (Circular 775 1285). Reston, USA: US Geological Survey.

776 Frith, H., Riley, S., Archer, L., \& Gleeson, K. (2005) Editorial. Qualitative Research in

777 Psychology, 2: 187-198. DOI: 10.1191/1478088705qp037ed

778 Frohoff, T. G. (2003). Interacting with captive dolphins. In T. Frohoff \& B. Peterson (Eds.), 779 Between species: Celebrating the dolphin-human bond (pp. 331-334). San Francisco, $780 \quad$ USA: Sierra Club Books.

781 Frohoff, T. G., \& Packard, J. M. (1995). Human interactions with free-ranging and captive

782 bottlenose dolphins. Anthrozoos, 8, 44-53. DOI: 10.2752/089279395787156527

783 Gaber, J., \& Gaber, S. L. (2004). If you could see what I know: Moving planners' use of

784

785

786

787

788

789

790

791

792

793

794

795

796

797

798

799

800

801

802

803

804

805

806

807

808

809

810 photographic images from illustrations to empirical data. Journal of Architectural and Planning Research, 21, 222-238. Retrieved from http://japr.homestead.com/files/GABER.pdf

Garland, R. (1991). The mid-point on a rating scale: Is it desirable? Marketing Bulletin, 2, 66-70. Retrieved from http://rangevoting.org/MB_V2_N3_Garland.pdf

Gibson, A. W., Newman, P., Lawson, S., Fristrup, K., Benfield, J. A., Bell, P. A., Nurse, G. A. (2014). Photograph presentation order and range effects in visual-based outdoor recreation research. Leisure Sciences, 4, 183-205. DOI: 10.1080/01490400.2013.862886

Hacket, J. (2016, March 17). Sea World Ends Controversial Captive Breeding of Killer Whales. Scientific American. Retrieved from https://www.scientificamerican.com/article/seaworld-ends-controversial-captivebreeding-of-killer-whales/

Hammersley, M., \& Gomm, R. (1996). Bias in Social Research. Sociological Research Online, 2. Retrieved from http://oro.open.ac.uk/20401/

Harley, H. E., Fellner, W., \& Stamper, M. A. (2010). Cognitive research with dolphins (Tursiops truncatus) at Disney's The Seas: A program for enrichment, science, education, and conservation. International Journal of Comparative Psychology 23, 331-343. Retrieved from http://escholarship.org/uc/item/92z8z9wq

Harper, D. (2002). Talking about pictures: A case for photo elicitation. Visual Studies, 17, 13-26. DOI: $10.1080 / 14725860220137345$

He, H., \& Chen, J. (2012). Educational and enjoyment benefits of visitor education centers at botanical gardens. Biological Conservation, 149, 103-112. DOI: 10.1016/j.biocon.2012.01.048

House of Commons Environmental Audit Committee. (2014). Sustainability in the UK Overseas Territories (Tenth report of session 2013-14). London, UK: The Stationery Office Limited.

Huggan, G. D. M. (2017). Killers: Orcas and their followers. Public Culture, 29, 287-309. DOI:

811 $10.1215 / 08992363-3749069$ 
812 Hughes, P. (2001). Animals, values and tourism - structural shifts in UK dolphin tourism

813

814

815

816

817

818

819

820

821

822

823

824

825

826

827

828

829

830

831

832

833

834

835

836

837

838

839

840

841

842

843

844

845

846

847

848

849

850

851 provision. Tourism Management, 22, 321-329. DOI: 10.1016/S0261-5177(00)00070-4

Hunt, T. D., Ziccardi, M. H., Gulland, F. M. D., Yochem, P. K., Hird, D. W., Rowles, T., \& Mazet, J. A. K. (2008). Health risks for marine mammal workers. Diseases of Aquatic Organisms, 81, 81-92. DOI: 10.3354/dao01942

International Trade Administration. (2014). 2014 market profile: Caribbean. Washington, D. C., USA: US Department of Commerce, International Trade Administration.

Jiang, Y., Lück, M., \& Parsons, E. C. M. (2007). Public awareness, education, and marine mammals in captivity. Tourism Review International, 11, 237-249. DOI: $10.3727 / 154427207783948829$

Jett, J. \& Ventre, J. (2015). Captive killer whale (Orcinus orca) survival. Marine Mammal Science, 31, 1362-1377. DOI: 10.1111/mms.12225

Kennedy, L., Naaman, M., Ahern, S., Nair, R., \& Rattenbury T. (2007). Proceedings of the $15^{\text {th }}$ ACM international conference on Multimedia, 631-640.

Kuo, V., \& Savidge, M. (2014, February 10). Months after 'Blackfish' airs, debate over orcas continues. CNN. Retrieved from http://edition.cnn.com/2014/02/07/us/blackfishwrap/index.html?iref=allsearch

Kyngdon, D. J., Minot, E. O., \& Stafford, K. J. (2003). Behavioural responses of captive common dolphins Delphinus delphis to a 'Swim-with-Dolphin' programme. Applied Animal Behaviour Science, 81, 163-170. DOI: 10.1016/S0168-1591(02)00255-1

Lake, H. (2018, February 6) Government moves to ban capture of cetaceans to keep in captivity. iPolitics. https://ipolitics.ca/2018/02/06/government-moves-ban-cetaceans-captivity/

Lange, K.E. (2016, May/June) Big Changes at Sea World. The Humane Society of the United States. Retrieved from http://www.humanesociety.org/news/magazines/2016/05-06/bigchanges-at-seaworld.html

Lerer, K. (2014, August 14). The End of SeaWorld. Huff Post Green. Retrieved from http://www.huffingtonpost.com/kenneth-lerer/the-end-ofseaworld_b_5680119.html?utm_hp_ref $=$ tw

Lindsay, B. (2018, January 18) Vancouver Aquarium will no longer keep whales, dolphins in captivity. $C B C$. Retrieved from https://www.cbc.ca/news/canada/britishcolumbia/vancouver-aquarium-will-no-longer-keep-whales-dolphins-in-captivity1.4492316

Lott, R. \& Williamson, C. (2017). Cetaceans in Captivity. In: Butterworth, A. (eds). Marine Mammal Welfare. Animal Welfare, vol 17. Springer, Cham. DOI: 10.1007/978-3-31946994-2_11

Lowe, A. (2014, July 18). Group wins fight against Blackbeard's Cay. The Nassau Guardian. Retrieved from http://www.thenassauguardian.com/bahamas-business/40-bahamasbusiness/48875-group-wins-fight-against-blackbeards-cay-

Luksenburg, J. A., \& Parsons, E. C. M. (2014). Attitudes towards marine mammal conservation issues before the introduction of whale-watching: A case study in Aruba (southern 
852

853

854

855

856

857

858

859

860

861

862

863

864

865

866

867

868

869

870

871

872

873

874

875

876

877

878

879

880

881

882

883

884

885

886

887

888

889

890

Caribbean). Aquatic Conservation: Marine and Freshwater Ecosystems, 24, 135-146.

DOI: 10.1002 aqc. 2348

Lunsford, T. R., \& Lunsford, B. R. (1995). The research sample, part I: Sampling. Journal of Prosthetics and Orthotics, 7, 17A. Retrieved from http://www.oandp.org/jpo/library/1995_03_105.asp

Makecha, R.N. \& Highfill, L.E. (2018). Environment Enrichment, Marine Mammals, and Animal Welfare: A Brief Review. Aquatic Mammals, 44, 221-230.

Marino, L. \& Lilienfeld, S.O. (1998) Dolphin-assisted therapy: Flawed Data, Flawed Conclusions. Anthrozoos 11, 194-200.

Marino, L. \& Lilienfeld, S.O. (2007). Dolphin-assisted therapy: More flawed data and more flawed conclusions. Anthrozoos, 20, 239-249. DOI: 10.2752/089279307X224782

Marino, L., Lilienfeld, S. O., Malamud, R., Nobis, N., \& Broglio, R. (2010). Do zoos and aquariums promote attitude change in visitors? A critical evaluation of the American Zoo and Aquarium Study. Society and Animals, 18, 126-138. DOI: $10.1163 / 156853010 X 491980$

Master, F. (2018, September 20). Tidal wave of Chinese marine parks fuels murky cetacean trade. Reuters. Retrieved from https://www.reuters.com/article/us-china-marineparksinsight/tidal-wave-of-chinese-marine-parks-fuels-murky-cetacean-tradeidUSKCN1M00OC

Mazet, J. A. K., Hunt, T. D., \& Ziccardi, M. H. (2004). Assessment of the risk of zoonotic disease transmission to marine mammal workers and the public: Survey of occupational risks (Final Report). Davis, USA: Wildlife Health Center School of Veterinary Medicine University of California.

Miles, L., \& Johnston, L. (2007). Detecting happiness: Perceiver sensitivity to enjoyment and non-enjoyment smiles. Journal of Nonverbal Behaviour, 31, 259-275. DOI: 10.1007/s10919-007-0036-4

Miller, L. J., Zeigler-Hill, V., Mellen, J., Koeppel, J., Greer, T., \& Kuczaj, S. (2013). Dolphin shows and interaction programs: Benefits for conservation education? Zoo Biology, 32, 45-53. DOI: $10.1002 /$ zoo.21016

Milman, O. (2016, April 25). Desert dolphins: plan to bring animals to Arizona for show outrages activists. The Guardian. Retrieved from https://www.theguardian.com/environment/2016/apr/25/dolphins-arizona-dolphinarisodysea-animal-rights-activists-outraged

Ministry of Finance Trade and Investment. (2013). Ministry of Finance Trade and Investment Strategic Plan FY 2013/14. Grand Turk, TCI: Ministry of Finance Trade and Investment.

Morisaka, T., Kohshima, S., Yoshioka, M., Suzuki, M., \& Nakahara, F. (2010). Recent studies on captive cetaceans in Japan: Working in tandem with studies on cetaceans in the wild. International Journal of Comparative Psychology, 23, 644-663. Retrieved from http://escholarship.org/uc/item/2r8461z4 
891 Nawijn, J. (2011) Determinants of Daily Happiness on Vacation. Journal of Travel Research, 50, 892 559-566. DOI: $10.1177 / 0047287510379164$

893 Orams, M. B. (1997). Historical accounts of human-dolphin interaction and recent developments

894

895

896

897

898

899

900

901

902

903

904

905

906

907

908

909

910

911

912

913

914

915

916

917

918

919

920

921

922

923

924

925

926

927

928

929

930

931 in wild dolphin based tourism in Australasia. Tourism Management, 18, 317-326. DOI: 10.1016/S0261-5177(96)00022-2

Orca Home. (2016). Orcas in captivity. Retrieved from http://www.orcahome.de/orcastat.htm

Parsons, C., \& Muhs, K. (1994). Field trips and parent chaperones: A study of self-guided school groups at the Monterey Bay Aquarium. Visitor Studies: Theory, Research, and Practice, 7, 57-61. Retrieved from http://www.informalscience.org/field-trips-and-parentchaperones-study-self-guided-school-groups-monterey-bay-aquarium

Parsons, E.C.M \& Rose, N.A. (2018) The blackfish effect: corporate and policy change in the face of changing public opinion on captive cetaceans. Tourism in Marine Environments. DOI: $10.3727 / 154427318 X 15225564602926$

Parsons, E. C. M. (2012). Killer whale killers. Tourism in Marine Environments, 8, 153-160. DOI: $10.3727 / 154427312 X 13491835451494$

Parsons, E. C. M., Bauer, A., McCafferty, D., Simmonds, M. P., \& Wright, A. J. (2013). An introduction to marine mammal biology and conservation. Burlington, USA: Jones and Bartlett Learning.

Parsons, E. C. M., de Calventi, I. B., Whaley, A., Rose, N. A., \& Sherwin, S. (2010). A note on illegal captures of wild bottlenose dolphins (Tursiops truncatus) from the coastal waters of the Dominican Republic. Journal of International Wildlife Law and Policy, 13, 240244. DOI: $10.1080 / 13880292.2010 .503123$

Patterson, K. W. (2010). Conservation, captivity, and whaling: A survey of Belize whalewatching tourists' attitudes to cetacean conservation issues (Master's thesis, George Mason University, USA). Retrieved from http://esp.gmu.edu/wpcontent/uploads/2013/05/KPatterson.doc

Perelberg, A., Veit, F., van der Woude, S. E., Donio, S., \& Shashar, N. (2010). Studying dolphin behavior in a semi-natural marine enclosure: Couldn't we do it all in the wild? International Journal of Comparative Psychology, 23, 625-643. Retrieved from http://escholarship.org/uc/item/9sz5j17r

Pernetta, C. A. P. (2014). Biodiversity news. Biodiversity, 15, 6-15. DOI: 10.1080/14888386.2014.890544

Pesman, P. D. (Producer), Stevens, F. (Producer), \& Psihoyos, L. (Director). (2009). The Cove [Motion picture]. USA: Diamond Docs, Fish Films, Oceanic Preservation Society, Participant Media, \& Quickfire Films.

Peterson, K. (2014, November 13). "Blackfish" continues to stalk wounded SeaWorld. CBS Moneywatch. Retrieved from http://www.cbsnews.com/news/seaworld-continues-tosuffer-after-blackfish/

Protests in TCI about possible dolphinaria. (2014, February). UK Overseas Territories Conservation Forum - Forum News, 42, pp. 11-12. Retrieved from http://www.ukotcf.org/pdf/fNews/42.pdf 
932 R Core Team (2015). R: A language and environment for statistical computing [Computer

933

934

935

936

937

938

939

940

941

942

943

944

945

946

947

948

949

950

951

952

953

954

955

956

957

958

959

960

961

962

963

964

965

966

967

968

969

970 software]. Vienna, Austria: R Foundation for Statistical Computing.

Rechberg, M. J. (2011). Dying to entertain us or living to educate us - a comprehensive investigation of captive killer whales, their trainers, and how the law must evolve to meet their needs. Journal of the National Association of the Administrative Law Judiciary, 31, 720-844. Retrieved from http://digitalcommons.pepperdine.edu/naalj/vol31/iss2/7

Reeves, R. R., Smith, B. D., Crespo, E.A., \& Notarbartolo di Sciara, G. N. (2003). Dolphins, whales and porpoises: 2002-2010 conservation action plan for the world's cetaceans. Gland, Switzerland and Cambridge, UK: IUCN.

Rose, N., Parsons, E. C. M., \& Farinato, R. (2009). The case against marine mammals in captivity. Washington, DC, USA: The Humane Society of the United States and World Society for the Protection of Animals.

Rose, N.A., Hanccock Snusz, G., Brown, D.M., \& Parsons, E.C.M. (2017) Improving Captive Marine Mammal Welfare in the United States: Science-Based Recommendations for Improved Regulatory Requirements for Captive Marine Mammal Care. Journal of International Wildlife Law \& Policy, 20, 38-72. DOI: 10.1080/13880292.2017.1309858.

Rossiter, J. C. (2009). A comparison of social desirability bias among four widely used methods of data collection as measured by the impression management subscale of the balance inventory of desirable responding (Doctoral thesis, Kent State University College and Graduate School, USA). Retrieved from https://etd.ohiolink.edu/!etd.send_file\%3Faccession\%3Dkent1240263500\%26disposition $\% 3$ Dinline

Saldaña, J. (2013). The Coding Manual for Qualitative Researchers [second edition]. London, UK: SAGE.

SeaWorld. (2013, December 20). SeaWorld: the truth is in our parks and people - an open letter from SeaWorld's animal advocates [Letter to the editor]. The Wall Street Journal. Retrieved from http://online.wsj.com/public/resources/documents/print/WSJ_A00720131220.pdf

Serres, A. \& Delfour, F. (2017). Environmental changes and anthropogenic factors modulate social play in captive bottlenose dolphins (Tursiops truncatus). Zoo Biology, 36, 99-111.

Shani, A, \& Pizam, A. (2008). Towards an ethical framework for animal-based attractions. International Journal of Contemporary Hospitality Management, 20, 679-693. DOI: 10.1108/09596110810892236

Shani, A, \& Pizam, A. (2009). Tourists' attitudes toward the use of animals in tourist attractions. Tourism Analysis, 14, 85-101. DOI: 10.3727/108354209788970225

Small, R. J., \& Demaster, D. P. (1995). Survival of five species of captive marine mammals. Marine Mammal Science, 11, 209-226. DOI: 10.1111/j.1748-7692.1995.tb00519.x

Thomas, A. (2017) Free Willy and Flipper by the Numbers. The Pudding. Retrieved from https://pudding.cool/2017/07/cetaceans/ 
971 Tizzi, R., Accorsi, P. A., \& Azzali, M. (2010). Non-invasive multidisciplinary approach to the

972

973

974

975

976

977

978

979

980

981

982

983

984

985

986

987

988

989

990

991

992

993

994

995

996

997

998

999

1000

1001

1002

1003

1004

1005

1006

1007

1008

1009

1010 study of reproduction and calf development in bottlenose dolphin (Tursiops truncatus): the Rimini Delfinario experience. International Journal of Comparative Psychology, 23, 734-776. Retrieved from http://escholarship.org/uc/item/9rr8k6jd

Turks and Caicos Islands Government. (2012a). Population and housing census. Grand Turk, TCI: Turks and Caicos Islands Government.

Turks and Caicos Islands Government. (2012b). Turks and Caicos Islands Development Strategy 2013-2017. Grand Turk, TC: Turks and Caicos Islands Government.

Turks and Caicos Tourist Board. (2015). Turks and Caicos Islands tourism statistics 2015. Grand Turk, TCI: Turks and Caicos Tourist Board.

Turks and Caicos Tourist Board, \& Department of Economic Planning and Statistics. (2009). Tourism. Grand Turk, TCI: Department of Economic Planning and Statistics.

Tyson, V. (2013, April 16). Dolphin Cove development in Grand Turk on the table, but Provo is off. Turks and Caicos Sun. Retrieved from http://suntci.com/dolphin-cove-developer-notconfident-of-local-approval-p885-106.htm

Ugaz, C., Valdez, R. A., Romano, M. C., \& Galindo, F. (2013). Behavior and salivary cortisol of captive dolphins (Tursiops truncatus) kept in open and closed facilities. Journal of Veterinary Behavior: Clinical Applications and Research, 8, 285-290. DOI: 10.1016/j.jveb.2012.10.006

Uyarra, M. C., Côté, I. M., Gill, J. A., Tinch, R. R. T., Viner, D., \& Watkinson, A. R. (2005). Island-specific preferences of tourists for environmental features: Implications of climate change for tourism-dependent states. Environmental Conservation, 32, 11-19. DOI: $10.1017 / \mathrm{S} 0376892904001808$

Visit Turks \& Caicos Islands. (2017, June 7) Salt Cay Whale Watching. Retrieved from https://www.visittci.com/salt-cay/things-to-do/whale-watching

Waerebeek, K.V., Sequeira, M., Williamson, C., Sanino, G.P., Gallego, P., \& Carmo, P. (2006). Live-captures of common bottlenose dolphins Tursiops truncatus and unassessed bycatch in Cuban waters: evidence of sustainability found wanting. Latin American Journal of Aquatic Mammals, 5, 39-48.

Webb, N. L., \& Drummond, P. D. (2001). The effect of swimming with dolphins on human well-being and anxiety. Anthrozoos, 14, 81-85. DOI: $10.2752 / 089279301786999526$

Wells, R.S. (2012). Letter to Japanese Government Regarding Dolphin and Small Whale Hunts. The Society for Marine Mammalogy. Retrieved from https://www.marinemammalscience.org/letters/letter-to-japanese-government-regardingdolphin-and-small-whale-hunts/

Whale and Dolphin Conservation Society, \& The Humane Society of the United States. (2003). Biting the hand that feeds: The case against dolphin petting pools. Chippenham, UK, Portland, USA and Washington, DC, USA: The Whale and Dolphin Conservation Society, and The Humane Society of the United States. 
1011 Whale and Dolphin Conservation Society. (2018, February 6). The fate of captive orcas.

1012 Retrieved from https:/uk.whales.org/wdc-in-action/fate-of-captive-orcas

1013 Williams, R., Krkošek, M., Ashe, E., Branch, T. A., Clark, S., Hammond, P. S., Hoyt, E., Noren, 1014 D. P., Rosen, D., Winship, A. (2011). Competing conservation objectives for predators

1015

1016

1017

1018

1019

1020

1021

1022

1023

1024

1025

1026

1027

1028

1029

1030 and prey: Estimating killer whale prey requirements for Chinook salmon. PLoS ONE, 6, e26738. DOI: 10.1371/journal.pone.0026738

Williams, V. (2001). Captive orcas 'dying to entertain you' - the full story. Chippenham, UK: Whale and Dolphin Conservation Society.

Williamson, C. (2008). Dolphin assisted therapy: can swimming with dolphins be a suitable treatment? Developmental Medicine and Child Neurology, 50, 477-477. DOI: 10.1111/j.1469-8749.2008.00477.x

Würsig, B. (2017). Marine Mammals of the Gulf of Mexico. In Ward, C. (eds) Habitats and Biota of the Gulf of Mexico: Before the Deepwater Horizon Oil Spill. Springer, New York, NY. DOI: 10.1007/978-1-4939-3456-0_5

Zaller, J., \& Feldman, S. (1992). A simple theory of the survey response: answering questions versus revealing preferences. American Journal of Political Science, 36, 579-616. DOI: $10.2307 / 2111583$

Zimmermann, T. (2014, September 9). Three former employees reveal the shocking realities of SeaWorld's dolphin feeding pools. The Dodo. Retrieved from https://www.thedodo.com/exclusive-three-former-employe-710451529.html 


\section{Table $\mathbf{1}$ (on next page)}

Types of bias potentially present in previous public opinion surveys relating to cetaceans. 


\begin{tabular}{|c|c|c|}
\hline $\begin{array}{l}\text { Type of } \\
\text { bias }\end{array}$ & Occurrence of bias & Sources \\
\hline Sample & $\begin{array}{l}\text { Where sample is from a population where for any } \\
\text { reason that population is almost uniformly more } \\
\text { informed than the general public on a public issue. } \\
\text { Sample bias can exist when non-random samples are } \\
\text { unintentionally enrolled as a result of respondent } \\
\text { selection techniques. }\end{array}$ & $\begin{array}{l}\text { Berk (1983); Marino } \\
\text { et al. (2010) }\end{array}$ \\
\hline Motivated & $\begin{array}{l}\text { Where researchers have a desired outcome, they can } \\
\text { convey this to respondents through subtle } \\
\text { communication during survey administration. } \\
\text { Researchers can also insert their own bias by } \\
\text { designing questions that they hope will either garner } \\
\text { responses they want, or that they will find } \\
\text { interesting. Whilst insertion of this can be conscious } \\
\text { and perhaps as a result unethical, it can also be } \\
\text { unconsciously inserted by well-meaning researchers. }\end{array}$ & $\begin{array}{l}\text { Hammersley and } \\
\text { Gomm (1997); } \\
\text { Marino et al. (2010) }\end{array}$ \\
\hline Ingratiation & $\begin{array}{l}\text { Respondents can adjust their answers to gain favour } \\
\text { or avoid disagreement with researchers. They may } \\
\text { adjust their answers to fit a hypothesis they believe } \\
\text { the researcher to be investigating. The nature of } \\
\text { questions and the manner or appearance of } \\
\text { researchers can invite this kind of bias. }\end{array}$ & $\begin{array}{l}\text { Back and Gergen } \\
(1943) \text {; Dijkstra } \\
\text { (1983); Marino et al. } \\
(2010)\end{array}$ \\
\hline $\begin{array}{l}\text { Social } \\
\text { desirability }\end{array}$ & $\begin{array}{l}\text { Respondents may give answers that they believe to } \\
\text { be socially desirable so that they appear to conform } \\
\text { to a societal position they believe is seen as } \\
\text { favourable. }\end{array}$ & Rossiter (2009) \\
\hline
\end{tabular}


Table 2 (on next page)

The demographic composition of the 292 respondents. 
1

\begin{tabular}{|c|c|c|c|}
\hline & Sub-Category & Count & Percent (\%) \\
\hline \multirow[t]{7}{*}{ Age (yrs.) } & $18-29$ & 42 & 11.7 \\
\hline & $30-39$ & 29 & 8.1 \\
\hline & $40-49$ & 86 & 24.0 \\
\hline & $50-59$ & 64 & 17.8 \\
\hline & $60-69$ & 40 & 11.1 \\
\hline & $70+$ & 17 & 4.7 \\
\hline & No response & 14 & 3.9 \\
\hline \multirow[t]{3}{*}{ Gender } & Male & 109 & 37.3 \\
\hline & Female & 171 & 58.6 \\
\hline & No response & 12 & 4.1 \\
\hline \multirow[t]{3}{*}{ Residency } & USA & 208 & 71.2 \\
\hline & Canada & 75 & 25.7 \\
\hline & Other \& no response & 9 & 3.1 \\
\hline \multirow[t]{3}{*}{ Parental status } & Has children & 136 & 46.6 \\
\hline & Has no children & 155 & 53.1 \\
\hline & No response & 1 & 0.3 \\
\hline \multirow[t]{3}{*}{ Visits to TCI } & Multiple & 152 & 52.1 \\
\hline & One & 137 & 46.9 \\
\hline & No response & 3 & 1.0 \\
\hline \multirow[t]{5}{*}{$\begin{array}{l}\text { Interest in } \\
\text { cruise tourism }\end{array}$} & $\begin{array}{l}\text { Have cruised/ } \\
\text { Would again }\end{array}$ & 76 & 35.2 \\
\hline & $\begin{array}{l}\text { Have cruised/ } \\
\text { Would not again }\end{array}$ & 64 & 29.6 \\
\hline & $\begin{array}{l}\text { Have never cruised/ } \\
\text { Would cruise }\end{array}$ & 33 & 15.3 \\
\hline & $\begin{array}{l}\text { Have never cruised/ } \\
\text { Would not cruise }\end{array}$ & 115 & 53.2 \\
\hline & No response & 4 & 1.9 \\
\hline \multirow{3}{*}{$\begin{array}{l}\text { Accommodation } \\
\text { type }\end{array}$} & All-Inclusive & 115 & 39.4 \\
\hline & Other & 175 & 59.9 \\
\hline & No response & 2 & 0.7 \\
\hline
\end{tabular}


Table 3 (on next page)

Visitation likelihoods of $\mathrm{TCl}$ tourists to each attraction. 
1

\begin{tabular}{|l|l|l|l|l|}
\hline \multirow{2}{*}{ Attraction } & \multicolumn{4}{|c|}{ Visitation Likelihood (\%) } \\
\cline { 2 - 5 } & \multicolumn{1}{|c|}{ very likely } & \multicolumn{1}{|c|}{ likely } & \multicolumn{1}{c|}{ unlikely } & very unlikely \\
\hline SWTD & 36.6 & 23.7 & 18.1 & 21.6 \\
\hline MMP & 15.4 & 23.8 & 28.0 & 32.9 \\
\hline Aquarium & 22.0 & 35.5 & 21.6 & 20.9 \\
\hline Botanical Gardens & 22.2 & 34.4 & 23.3 & 20.1 \\
\hline Maritime Museum & 5.9 & 23.7 & 30.0 & 40.4 \\
\hline Craft Market & 17.4 & 31.4 & 26.1 & 25.1 \\
\hline
\end{tabular}

2 


\section{Table 4(on next page)}

Summary of qualitative opinions offered by $\mathrm{TCl}$ tourists on captive cetacean attractions. 
1

\begin{tabular}{|c|c|c|c|c|c|}
\hline & & \multicolumn{2}{|c|}{ ММР } & \multicolumn{2}{|c|}{ SWTD } \\
\hline & \multirow[t]{2}{*}{$\begin{array}{l}\text { Visitation } \\
\text { Likelihood (\%) }\end{array}$} & $\begin{array}{l}\text { likely / very } \\
\text { likely to } \\
\text { visit }\end{array}$ & $\begin{array}{l}\text { unlikely / } \\
\text { very unlikely } \\
\text { to visit }\end{array}$ & $\begin{array}{l}\text { likely / } \\
\text { very likely } \\
\text { to visit }\end{array}$ & $\begin{array}{l}\text { unlikely / } \\
\text { very unlikely } \\
\text { to visit }\end{array}$ \\
\hline & & $(\mathrm{N}=5)$ & $(\mathrm{N}=48)$ & $(\mathrm{N}=26)$ & $(\mathrm{N}=51)$ \\
\hline \multirow[t]{7}{*}{$\begin{array}{l}\text { Negative } \\
\text { attitudes }\end{array}$} & $\begin{array}{l}\text { Animal welfare } \\
\text { concerns }\end{array}$ & 20.0 & 72.9 & 15.4 & 56.9 \\
\hline & $\begin{array}{l}\text { Not } \\
\text { entertaining }\end{array}$ & - & 10.4 & - & 21.6 \\
\hline & $\begin{array}{l}\text { Human welfare } \\
\text { concerns }\end{array}$ & - & 4.2 & 3.8 & 9.8 \\
\hline & $\begin{array}{l}\text { Overly } \\
\text { commercial } \\
\text { experience }\end{array}$ & - & 14.6 & - & 3.9 \\
\hline & $\begin{array}{l}\text { Conservation } \\
\text { concerns }\end{array}$ & - & 4.2 & 3.8 & 2.0 \\
\hline & $\begin{array}{l}\text { Attractions too } \\
\text { costly }\end{array}$ & - & - & - & 2.0 \\
\hline & $\begin{array}{l}\text { Unclear } \\
\text { reasoning }\end{array}$ & - & 4.2 & - & 5.9 \\
\hline \multirow{2}{*}{$\begin{array}{l}\text { Positive } \\
\text { attitudes }\end{array}$} & Entertaining & 100.0 & - & 96.2 & 2.0 \\
\hline & $\begin{array}{l}\text { Appropriate for } \\
\text { children }\end{array}$ & 20.0 & - & 34.6 & 11.8 \\
\hline \multirow{2}{*}{$\begin{array}{l}\text { Influence } \\
\text { of media } \\
\text { on } \\
\text { opinions }\end{array}$} & $\begin{array}{l}\text { Cited media } \\
\text { influence }\end{array}$ & - & 16.7 & 3.8 & 2.0 \\
\hline & $\begin{array}{l}\text { Stated they had } \\
\text { seen Blackfish }\end{array}$ & - & 14.6 & 3.8 & 2.0 \\
\hline
\end{tabular}


Table 5 (on next page)

Visitation likelihoods of TCI tourists to captive cetacean attractions by demographic group. 


\begin{tabular}{|c|c|c|c|c|}
\hline \multirow{2}{*}{$\begin{array}{l}\text { Visitation } \\
\text { Likelihood (\%) }\end{array}$} & \multicolumn{2}{|c|}{ MMP } & \multicolumn{2}{|c|}{ SWTD } \\
\hline & $\begin{array}{l}\text { likely / very } \\
\text { likely to visit }\end{array}$ & $\begin{array}{l}\text { unlikely / very } \\
\text { unlikely to visit }\end{array}$ & $\begin{array}{l}\text { likely / very } \\
\text { likely to visit }\end{array}$ & $\begin{array}{l}\text { unlikely / very } \\
\text { unlikely to visit }\end{array}$ \\
\hline \multicolumn{3}{|c|}{ Accommodation Type } & & \\
\hline All-inclusive & 48.7 & 51.3 & 24.8 & 75.2 \\
\hline Other & 69.0 & 31.0 & 49.4 & 50.6 \\
\hline \multicolumn{3}{|c|}{ Interest in cruise tourism } & & \\
\hline Interested & 42.6 & 57.4 & 67.0 & 33.0 \\
\hline Not interested & 36.6 & 63.4 & 56.0 & 44.0 \\
\hline \multicolumn{3}{|l|}{ Residency } & & \\
\hline USA & 41.7 & 58.3 & 65.7 & 34.3 \\
\hline Canada & 34.2 & 65.8 & 50.0 & 50.0 \\
\hline Other & 22.2 & 77.8 & 22.2 & 77.8 \\
\hline \multicolumn{3}{|l|}{ Age (yrs.) } & & \\
\hline $18-29$ & 37.5 & 62.5 & 70.0 & 30.0 \\
\hline $30-39$ & 41.4 & 58.6 & 69.0 & 31.0 \\
\hline $40-49$ & 50.6 & 49.4 & 68.2 & 31.8 \\
\hline $50-59$ & 28.6 & 71.4 & 58.7 & 41.3 \\
\hline $60-69$ & 42.1 & 57.9 & 48.7 & 51.3 \\
\hline $70+$ & 11.8 & 88.2 & 35.3 & 64.7 \\
\hline \multicolumn{3}{|l|}{ Gender } & & \\
\hline Female & 35.3 & 64.7 & 59.4 & 40.6 \\
\hline Male & 44.8 & 55.2 & 62.3 & 37.7 \\
\hline \multicolumn{3}{|l|}{ Visits to TCI } & & \\
\hline One & 43.6 & 56.4 & 64.0 & 36.0 \\
\hline Multiple & 33.3 & 66.7 & 56.9 & 43.1 \\
\hline \multicolumn{3}{|l|}{ Parental Status } & & \\
\hline Has children & 44.7 & 55.3 & 64.7 & 35.3 \\
\hline $\begin{array}{l}\text { Has no } \\
\text { children }\end{array}$ & 34.6 & 65.4 & 56.9 & 43.1 \\
\hline
\end{tabular}




\section{Figure 1}

Map of the Turks and Caicos Islands.

Islands in the TCl associated with current or potential cetacean tourism. Map from Esri, HERE, GARMIN (c) OpenStreetMap contributors, and the GIS user community. The data is available under the Open Database License, licensed as CC BY-SA .

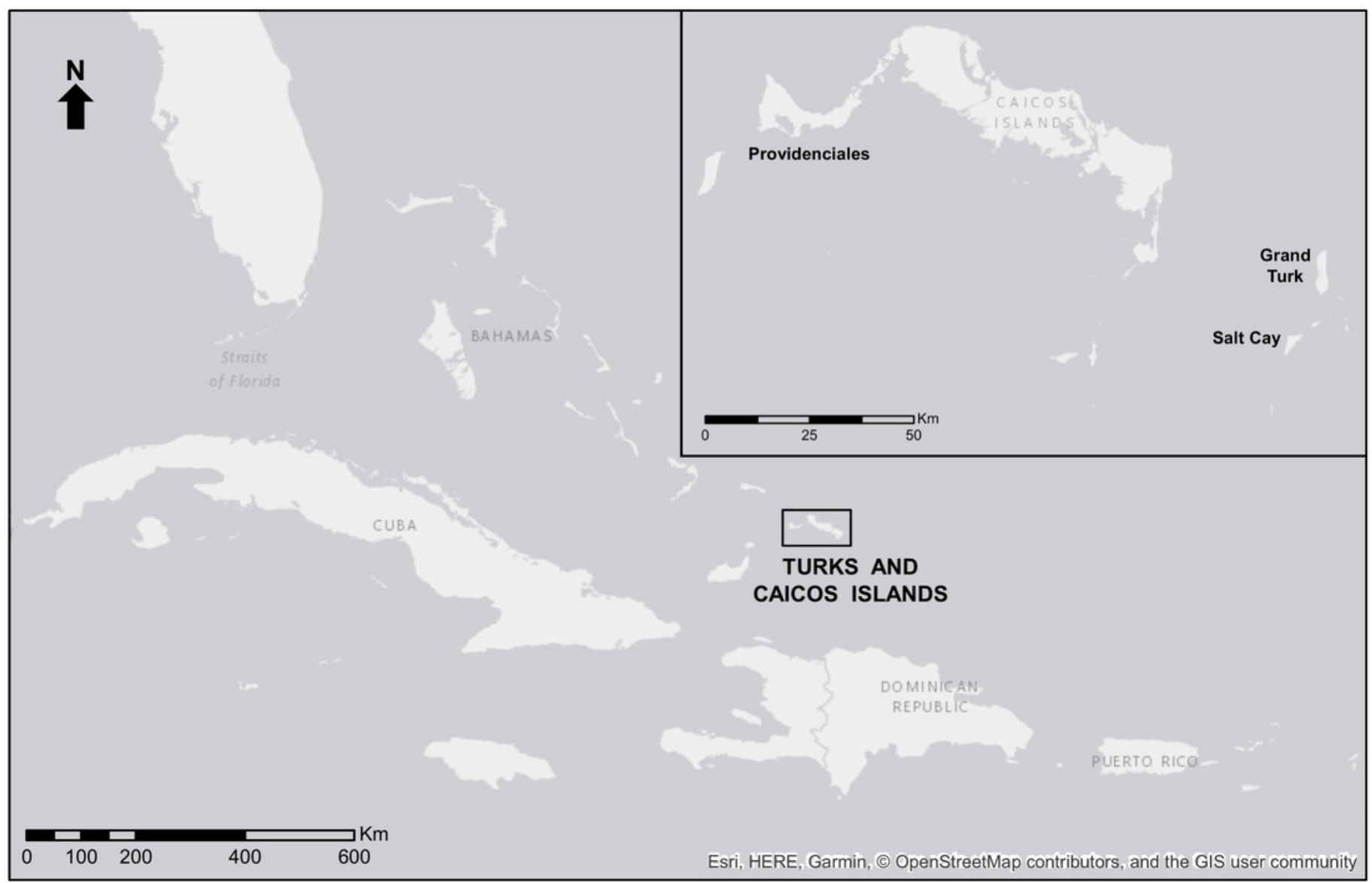


Figure 2

Tourists' visitation likelihoods for the attractions.

Significant groupings of tourists' visitation likelihoods for the six attractions including swimwith-the-dolphins (SWTD) and marine mammal park (MMP). Asterisks summarise the value of $\mathrm{P}$ more generally $(* \mathrm{P} \leq 0.05, * * \mathrm{P} \leq 0.01, * * * \mathrm{P} \leq 0.001)$.

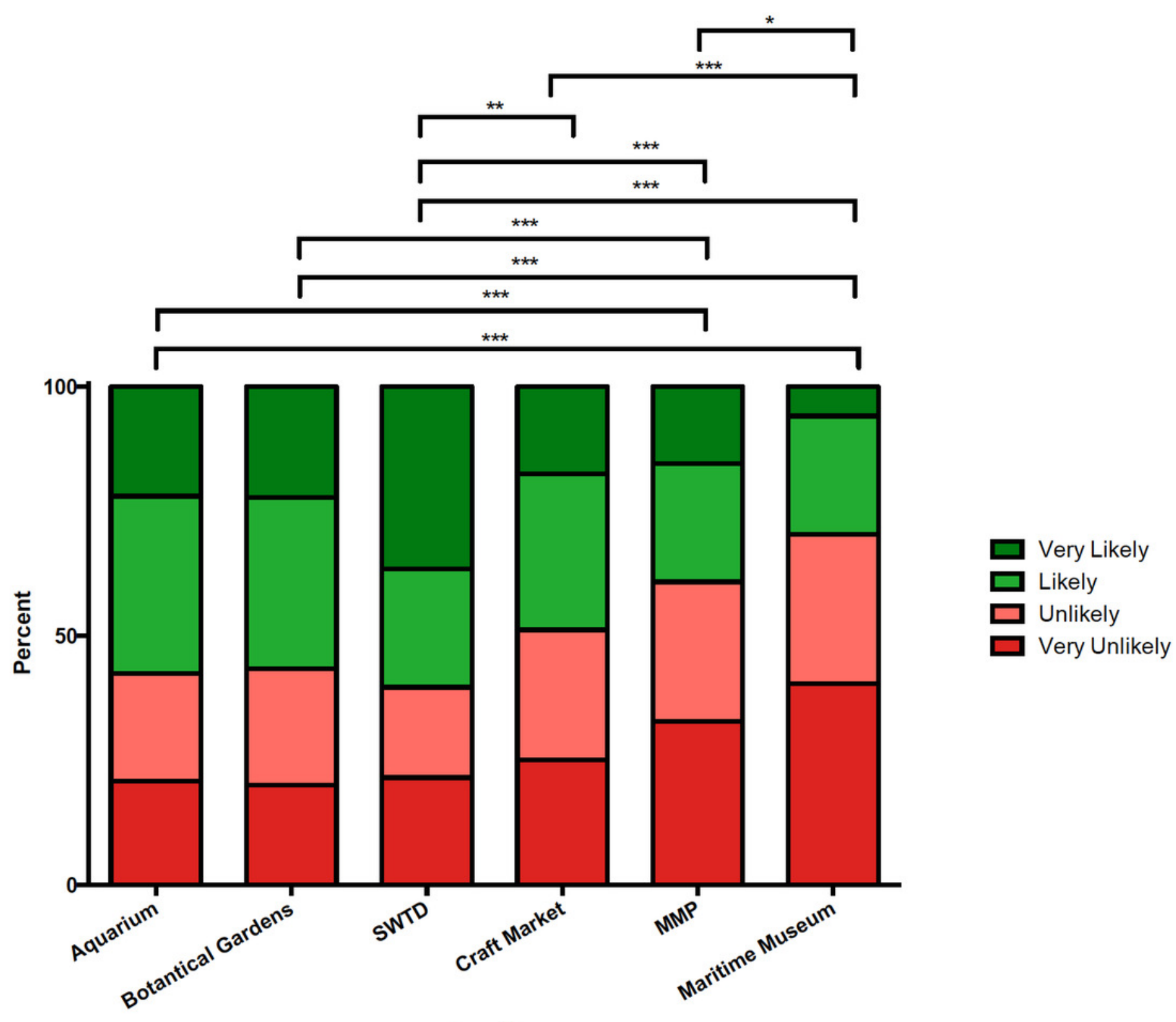

Location 